Author's postprint:

SINGH-GARHA, Nachatter (2020) "Punjabi irregular immigration to Italy and Spain: causes and consequences". South Asian Diaspora, https://doi.org/10.1080/19438192.2020.1793449

12 (2): 195-211 (ISSN: 1943-8192). 


\title{
Punjabi irregular immigration to Italy and Spain: causes and consequences
}

\author{
Nachatter Singh Garha
}

Postdoc Researcher, Centre for Demographic Studies, UAB, Spain.

\begin{abstract}
Since 1990, an irregular migration industry has flourished in different cities of Indian Punjab because of the eagerness among young men to emigrate at any cost and increased border controls imposed by the European Union. In Europe, the majority of irregular immigrants from Punjab end up in Spain or Italy due to continuous regularization programs, support from social networks and the availability of informal jobs. In this paper, with a thematic analysis of 72 in-depth interviews with irregular immigrants from Punjab in Italy or Spain, their relatives in Punjab and members of the host community, this paper explores the main causes and consequences of Punjabi irregular immigration in Italy and Spain.
\end{abstract}

Keywords:

Punjabi irregular migration, causes, consequences, qualitative study, Italy, Spain.

\section{Introduction}

Over the last two decades, irregular immigration has become a cause for concern in several countries of the European Union (EU), which are struggling to control the influx of irregular migrants into their territories. In 2017, Frontex (European Border and Coast Guard Agency) reported that 204,719 irregular border crossings were detected at the EU's external borders. The exact number of irregular immigrants in the EU countries is unknown. However, the most recent data confirms the presence of 1.9 to 3.8 million irregular immigrants in the EU-27 countries in 2008 (Kovacheva and Vogel, 2009). Most of them were entered legally and subsequently surpassed their tourist visa or temporary residence permits, or for different reasons did not return to their country of origin after they were denied asylum or other rights to remain in the country (Krause, 2011; Düvell, 2011a). The other important part consists of the migrants who have crossed the land or sea borders of the EU with the help of human traffickers (Spena, 2016). In the EU countries, the political response over irregular immigration consists of two contradictory policies: first policy approach advocates the restrictions on the entry of irregular immigrants through strict border controls and the deportation of immigrants who entered irregularly or become irregular for any reason (also known as North European Model); and second policy approach advocates the integration and regularization of irregular immigrants who have already entered the EU (also known as South European Model). However, both models have failed to respond the problem of irregular immigration in the 
EU (Andersson, 2016). Spain and Italy, are the main entry gates for irregular immigrants due to their geographical location. A majority of the irregular immigrants in Europe originate from African and Asian countries (Morehouse and Blomfield, 2011). Punjabi community (an ethnic group from Punjab, a north-western state in India) makes a small fraction of the total influx of irregular immigrants to the EU. However, it constitutes a significant part of the irregular immigration from India to Spain and Italy (Saha, 2009).

Migration has always been a prominent feature of the Indian Punjabi community (Barrera and Dusenbery, 1989; Tatla, 1999). They have migrated to all developed countries around the world (Garha and Domingo, 2017). Large-scale migration of low skilled Punjabi men has met with restrictions in almost all developed countries (Geddes and Taylor 2013). Over the last few decades, the immigration retention policies in the EU and North American countries and eagerness to emigrate to the first world countries among Punjabi men have transformed the regular migration of unskilled labour to irregular migration or human trafficking. Since the 1990s, Punjab has become the leading exporter of irregular migrants from India (Bhawara, 2013; Kumar, 2009). According to a report published by the United Nations Office on Drugs and Crime, every year twenty thousand young men migrate irregularly from Punjab (UNDOC, 2009). They use different methods to go abroad, including the misuse of legal channels, such as obtaining short-term work permits by bribing employers in the Western countries, misuse of sponsorships sent by family members settled abroad, paper-marriages with a foreign citizen or fake study visas (Zaidi, 2007); and some clandestine ways, such as donkey flights or human smuggling (Smith, 2014). At the time of Indian independence (1947), Punjab was one of the richest states in India. Over the period of Green Revolution (19661980), it became the bread basket of India, with the highest per capita income and high status of living (Aiyar, 2013). Despite a strong economy, in the first decade of the twenty-first century, it had the highest number of irregular migrants compared to all other states of India. It raises some questions, such as, over the last two decades, what happened in Punjab that people here have become so desperate to emigrate (regularly or irregularly) that they are risking their lives and paying mammoth sums of money to travel agents for irregular migration? Secondly, how has this irregular migration has been shaping the lives of migrants and their families? And, finally, how is it affecting the security and the socio-economic environment of the host countries?

In Italy, the large-scale immigration of Punjabi men began in the 1990s (Garha and Domingo 2019). In this influx, a large number of irregular young men with little education and skills entered Italy in search of manual jobs, regularisation of their legal status, and opportunities for permanent settlement. Information regarding the exact number of Punjabi immigrants in Italy is not available. However, according to the respondents, in 2017, the number of Punjabi immigrants in Italy was around one lakh and ten percent of them were irregular. Most of the Punjabi community in Italy consists of Sikhs who have established their temples in many cities of Italy that provide essential support to irregular immigrants (Gallo, 2012). They are mainly concentrated in Lombardy (Brescia, Bergamo, and Mantua provinces) and Lazio (Rome and Latina provinces) regions of Italy (Garha 2019). Their main occupations are dairy farming, agriculture, and manual labour in small scale food processing, leather, and metal industry (Sahai and Lum 2013). Similar to Italy, in Spain, the large-scale immigration of young Punjabi men began in the 1990s and they settled 
along with the Mediterranean coast and Balearic Islands (Garha, 2020). According to respondents, in 2017, the number of Punjabi immigrants in Spain was around 20 thousand, of them 15 to 20 percent were irregular. Majority of them were engaged in the catering, agriculture, and construction sectors (Garha and Domingo 2019).

In previous studies on irregular immigration, researchers have mainly focused on its impact on the labour market and civil society of the receiving countries (Jahn and Straubhaar, 1998; Düvell and Jordan 2003; Düvell, 2006; Hanson, 2007, Iglitzka et al., 2011). However, its causes and consequences for the irregular immigrants and their families is often ignored. The main purpose of this paper is to explore the underlying causes and consequences of irregular migration for all actors (migrants, their families and host countries) involved in Punjabi irregular migration. This paper will contribute to the research on irregular migration by providing a comprehensive understanding of the phenomenon from the point of view of three different collectives: irregular immigrants, their family members in India and the local community members in the receiving countries who have some direct or indirect contact with irregular immigrant. It also presents a dark side of immigration policies in India and the EU, which have failed to address this issue. This paper only focus on the Punjabi community (because of high numbers of irregular immigrants), however, I believe that the results will be identical for other irregular immigrants from South Asian and African countries. The main reasons behind the selection of Spain and Italy for this study are: first, these countries have received the largest number of irregular migrants from Punjab in continental Europe (see Bhawara, 2013); second, both countries follow the South European immigration model and have accommodating regularization policies for irregular immigrants (King and Zontini, 2000; Sabater and Domingo, 2012); and, finally, both countries have received a massive influx of unskilled Punjabi men in the 1990s, when the EU was moving towards strict border controls policies (Garha and Domingo, 2019).

\section{Irregular migration: concept and theory}

Over the past few decades, irregular immigration has become a global phenomenon. However, there is still no internationally accepted definition of the term 'irregular migrant'. It makes it very difficult to know the exact number of irregular migrants around the world (Massey and Capoferro, 2004). Broadly, the term covers all migrants who do not meet the conditions established for entering and remaining in a country, either at the time of entry or afterwards (Clandistino, 2009). Therefore, an irregular migrant is defined as someone who crosses international borders without adequate documents or who violates the conditions established for entering another country (Jordan and Düvell, 2002: 15). Uehling (2004) emphasized that the recognition of multiple routes towards irregularity is fundamental to define irregular migration. The three main routes include: people entering a country without due authority, either through a clandestine entry or with fraudulent documents; people who enter with authority, but overstay their visas; and people who deliberately use the asylum system without complying with asylum requirements. In the EU, the term 'irregular' is used to refer to third-country nationals who enter the EU by land, sea or air with the assistance of networks of traffickers or organized criminal groups (Düvell, 2008). However, the term is also used to refer to the 
people who legally entered the EU, but overstayed their residence permits or visitor visas, and for the people who stayed in the country even after the rejection of their asylum application. Therefore, the main distinction for most receiving countries with respect to their irregular migrants is between irregular entry and irregular stay (de Haas, 2008). The European migration network defined irregular migration as "a movement that occurs outside the regulatory norms of sending, transit and receiving countries" (European Migration Network, 2013, p.82).

The term irregular migration appears frequently in political and academic discourses. However, it still lacks a solid theoretical base (Bommes, 2003). The existing discourse describe irregular immigration as a problem for the host countries, but ignores the underlying causes behind it (Baldwin-Edwards 2009). Several authors have argued that instead of dealing with irregular immigration as a crime, state authorities should consider it as a political or legal construction to include certain types of migrants and exclude others (Calavita, 1998; Genoa, 2002; Düvell 2011b). Samers (2004: 28) explains that states do not create specific channels for legal migration to meet their economic and political needs, but as a reaction to irregular immigration, they produce categories such as illegal, irregular or undocumented, to exclude all those who do not follow their rules. Andersson (2016: 1072) claims that "politicians have been looking in the wrong 'place' (the border) and at the wrong kind of measures (security) to 'solve' the migration 'problem'... punitive border measures do not work; instead, the 'mixed migration' flows of today need to be dealt with through other means, including economic instruments at home and more intelligent interventions abroad".

Regarding the irregular migration, Hillman and Weiss (1999: 585) presented 'permissible illegal migration' theory, which states that 'in many countries laws are not enforced against visibly present illegal migrants... [who] tend to be concentrated in particular sectors'. It is 'an endogenous-policy model where selective sector-specific illegality transforms illegal immigrants from non-sector specialized to sector-specific factors of production'. In their article on theorization of irregular migration, Cvajner and Sciortino (2010: 389) propose that 'a theory of modern society cantered on its form of differentiation may help to clarify both the political dimension of contemporary international mobility, the variety of irregular statuses existing in the foreign population of receiving countries, and the condition of inclusion and exclusion of irregular migrants'. Their main argument is 'to analyse irregular migration within a vision of modernity as differentiation helps to highlight how the structural preconditions of irregular migration are not to be seen as pathology or an imperfection but rather as part and parcel of the very same organization of world society'.

\section{Data Sources and Methodology}

The data has been collected through seventy-two semi-structured in-depth interviews. Of the total interviews, 48 with the Punjabi immigrants, who irregularly entered Europe or become irregular after expiring of their legal visas and currently living in Spain (26) or Italy (22), 16 with their relatives in Punjab and 8 with the member of the host communities (neighbours, public servants, school teachers or members of some NGOs), 
who have some direct or indirect contact with Indian immigrants in both countries. The interviews were conducted during the period between November 2015 and February 2018 , in the seven cities where Indians are mainly concentrated in Italy, i.e. Rome $(13,702)$, Brescia $(15,028)$, and Latina $(10,003)$, and Spain i.e. Barcelona $(5,895)$, Valencia (2,276), Madrid (2,262), and Santa Cruz de Tenerife $(1,146)$.

Respondents were selected while using the snowball sampling technique. For those interviewed in Spain and Italy, the eligibility criterion was that a person must had an irregular entry or irregular stay in one of these countries. Since in Punjabi community irregular immigration is strictly a characteristic of young men, all respondents in this category were men in the age group of 20 to 40 years. In India, the respondents were family members (parents, wife, siblings or children) of irregular migrants. Before interviews, all respondents were informed about the nature and contents of the study through a letter of information. All participants have signed a consent letter regarding their voluntary participation. The interviews were conducted with a semi-structured questionnaire and immigrant respondents were asked to express themselves on the following topics: family history, migration history, main causes of migration, forms and routes, cost of migration, life at destination, problems due to irregularity, attitude of the local population, regularization process, current socioeconomic condition and future perspectives. The interviewed family members were asked to explain their role in the migration process and the consequences of this on their lives. Host respondents were asked to express their views on the effects of irregular immigration on their neighbourhood, social environment and labour market. Interviews were conducted at the usual place of residence of the respondents or at public places like Sikh temples, cultural associations, etc. All interviews were conducted in one of the following languages: Punjabi or English, taking into account the convenience of respondents. Average duration of the interviews was 45 minutes and all the interviews were audio recorded. All interviews were deposited in the repository of intellectual material in Center for Demographic Studies in Barcelona, with an exclusive access to the researchers involved in the project. Pseudo names are used in quotations to ensure the unanimity of respondents.

For data analysis, we used 'Grounded Theory', which is a rigorous data production and analysis strategy, using an inductive approach, where the researcher moves between data and theory in order to understand the case, produce data, creates a new or modify existing theory, and analyse as one goes along (Strauss and Corbin, 1994). All the interviews were coded in the Atlas.ti computer programme using a thematic classification. This prepared the interviews for theme-by-theme analysis. Each interview was summarized in a "portrait" based on a thematic grid (migration history, arrival in Europe, situation at the destination, access to the labour market, regularisation and family reunion). These portraits were illustrated by quotations.

\section{Main causes behind the irregular migration from Punjab}

Immigration is often considered as a result of several push and pull factors that traverse economic, social, demographic or political considerations (Lee, 1966; de Haas, 2011). 
Additionally, structural mechanisms that range from the lack of legal immigration channels to inefficient procedures and the specific labour demands of informal economies also contribute to the irregular migration (Düvell, 2011a; Reyneri, 2003; GarcésMascareñas, 2010; Castle et al., 2012). The main causes behind Punjabi irregular immigration (Fig. 1) are discussed below:

\section{Determinants at origin}

A detailed analysis of the demographic and socio-economic profile of the respondents revealed that the irregular migration from Punjab is a characteristic of young men (15 to 30 years) from rural areas with little education and lower skills. The 1980s political unrest in Punjab and the 1990s neoliberal shift in the Indian economic policies caused decay of the public education system and the vocational training institutes in Punjab. It deprived the young generation in rural Punjab of good education and professional training, which in turn made them unqualified for any job in public administration and private companies in India, or for a decent job abroad. Their recruitment in the Indian army, which was their second most important occupational niche since the colonial times, was also reduced drastically. This loss of work opportunities had serious consequences for the self-esteem of Punjabi men who are expected to play the role of breadwinners of their families (Garha, 2020). Therefore, to escape unemployment and poverty, they began to migrate irregularly at a higher cost and by all means. As explained by Kartar, 56, male, father of an irregular immigrant, "In our villages [northern India], young men are poorly educated and unskilled. They are not eligible for any government job in India and other high qualified jobs abroad. So they forced their parents to pay huge sums of money to travel agents [smugglers of people] to go abroad."

The eagerness of young men to emigrate from Punjab at any cost or by any means has contributed to the expansion of irregular migration industry in all major cities of Indian Punjab. A network of people starting from the village agents, who convince young men to migrate through clandestine ways and collect money from their family, until the human smugglers who smuggle them to European or North American countries, participate in this business. Jagtar, 52, male, father of an irregular migrant, explains "In today's Punjab, everyone wants to emigrate. So the agents charge heavily... for Europe 12 lakh rupees [15000 Euros), for the United Kingdom up to 15 lakh rupees, and for the North American countries from 25 to 30 lakh rupees." People in Punjab have little faith in the legal channels of emigration, as they are cumbersome, impersonal, non-transparent and the success rate is very low. They have more trust in their local travel agents. They do not consider the dangers and economic loss involved in irregular immigration. As explained by Manjit, 48, female, mother of an irregular migrant, "Our village agents are very efficient in Kabutarbazi [human smuggling]. Now they charge money when the person arrives at his desired destination in Europe. Hence, when one succeeds, two more get ready to follow him". For the prospective migrants, ends justify means, the high success rate of agents in smuggling people into the European countries encourages others to follow the same route.

The lack of emigration policies for unskilled workers in India who want to emigrate to the EU is one of the main causes behind the success of irregular immigration 
industry. As explained by Sandeep, 36, male, irregular migrant, "In India, I looked for all legal ways to emigrate, but there were no options for unskilled workers... I had no other option than paying 9 lakh rupees to migrate irregularly". Local politicians and administrators in Punjab ignore irregular migration because it reduces the number of unemployed people in the state. Harjot, 34, male, irregular migrant, says "Indian government don't bother about the people who pay huge sums of money and risk their lives to irregularly enter Europe, for them it reduces their unemployed population". Some interviewees also highlight the role of 'corruption' in encouraging the irregular migration. The corrupt immigration officers help travel agents to forge documents and smuggle people to the Western countries. As explained by Kuljit, 34, male, irregular migrant, "Corruption in Indian immigration department and the embassies who issue Schengen visas are also responsible for irregular migration... it is impossible without their involvement".

The social acceptance of irregular emigration as an 'emigration strategy' has also contributed to the growth of irregular migration business. Currently, irregular migration is not a social stigma in Punjab. As explained by Gurmeet, 56, male, Gurudwara head, Punjab, India, "Now people don't feel ashamed of irregularly entering the Western countries. Sometimes they end up in jail while crossing international borders illegally, but now even going to jail is not a social stigma for emigrants and their families, rather it has become an accepted part of their emigration strategy". The acceptance of risks involved in irregular migration as a part of migration strategy for unskilled workers has increased the cases of irregular migration. Owing to the false image of the western countries in Punjab, as the land of infinite opportunities, created by the irregular immigrants who somehow have managed to get regularized in one of the EU countries, young Punjabi men feel that they can also earn enormous wealth in a short time by emigrating irregularly. Moreover, the optimistic depiction of Europe in Bollywood movies also lure rural youth to pay high prices and take risky journeys. As highlighted by Pritpal, 37 , male, irregular worker, "I was not aware about the reality of Europe, I thought it will be very beautiful, like they present in Bollywood movies... When one of my neighbours returned from Italy, he told me that in Italy the life is very good and he is earning huge money. From that moment, I start trying to convince my parents to arrange money for my journey".

Figure 1. Main causes behind the irregular immigration from Indian Punjab. 


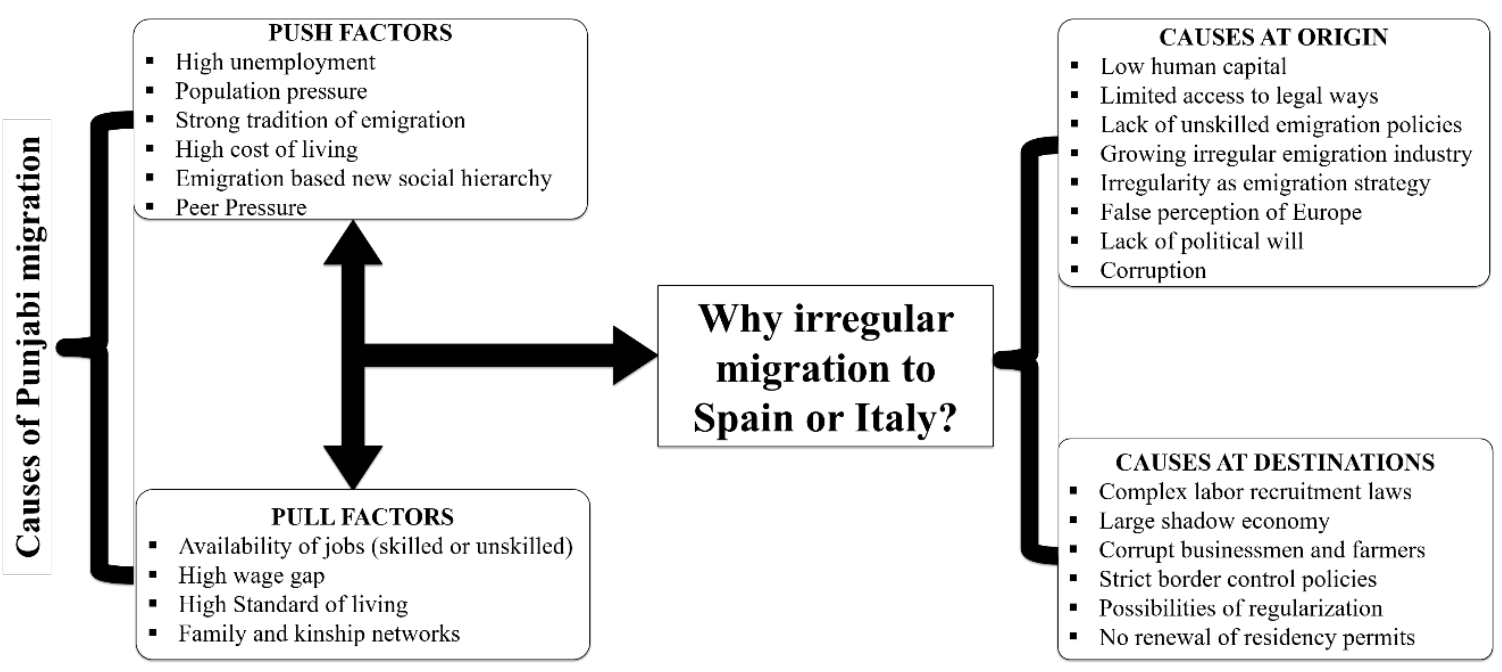

Source: Own elaboration.

\section{Determinants at destination countries}

Spain and Italy have big shadow economies that function with the use of informal labour (Alañón and Gómez-Antonio, 2005; Schneider and Enste, 2000). This informal labour consists of the irregular immigrants, who accept work at low wages, without any legal contracts (Reyneri, 2003). Most of the respondents in both countries have confirmed that one of the main reasons for their irregular migration was the availability of manual jobs in agriculture and service sectors in both countries. These low paid jobs require less skills and are often neglected by the native workers. As explained by Manpreet, 36, male, irregular migrant "the availability of jobs in the agricultural and hospitality sector for the irregular migrants in Italy attracts many new immigrants annually". The huge wage differences between India and the western countries acts as an incentive for the young men who take the risk of irregular migration to Europe. As explained by Malkit, 36, male, irregular migrant, "what I earn in one day by cleaning a cow shed in Italy, I could not earn in India in one month doing the same work." Some respondents also highlight the role of complex labour laws in Italy and Spain regarding the recruitment of migrant workers, as a reason that encourages the use of irregular migrants. Ranjit, 32, male, irregular migrant, explains “Here [in Italy] local people don't want to work in agriculture, therefore, the farmers depend on migrant labour. They want foreign labour, but the complex laws regarding the legal recruitment of immigrant workers force farmers to hire irregular workers".

According to some respondents, their social networks played an important role in facilitating their irregular migration. In Punjabi community, when one family member gets settled abroad, it is his prime duty to help others to emigrate. These networks provide basic necessities to the newcomers and information about the ways of irregular entry, immigration laws, work opportunities for irregular workers, immigrant NGOs and public services available for irregular immigrants in host countries (Garha and Paparusso, 2018). Some irregular immigrants from Punjab today have their own businesses in Spain or Italy. Their success stories encourage others to follow their footsteps. Jasjit, 48, male, 
father, explains "All my cousins who had emigrated irregularly, now have their own businesses. Their success stories encouraged my sons to emigrate irregularly." Some respondents also claim that irregular immigration is a result of strict border control policies and cumbersome regularisation laws. If they were allowed to enter and work legally, they will return after the end of every harvest season and come again when the next season begins. However, the strict border laws prohibit their circular migration, and force them to stay here even when they do not have any work. They also claim that strict border controls have failed to cut the influx of irregular immigrants, but has only raised its cost. Gagan, 32, male, irregular migrant, explains "Irregular migration does not decline with strong border controls, only its price increases. Initially, agents used to charge 3 to 4 lakh rupees, but as the border security increased, now they charge 8 to 12 lakh rupees".

The possibility of getting regularized after spending some time in the country, which is not possible in many North European countries, also attracts irregular migration to Spain and Italy (González-Enrique, 2009). In Spain a continuous system of regularization called 'Arraigo' is used to regularize migrants who have stayed for at least three years in Spain and have learned Spanish and any other regional language, and have a full-time work contract for at least one year (Sabater and Domingo, 2012). In Italy, the government allows regularization periodically to serve the needs of some particular sectors, like agriculture and domestic care (Finotelli and Arango, 2011). This hope of becoming a regular resident of Europe, attracts many irregular immigrants from Punjab and other diaspora countries to Italy and Spain. According to Hari, 41, male, irregular immigrant, "Spain has the best regularization laws in Europe. Most of the Indian immigrants, who irregularly enter Europe, come here to get legalized". Moreover, people who successfully enter Italy or Spain are rarely deported to their origin countries. In Spain, irregular immigrants have the right to get registered in municipal registers, and have access to medical facilities, public libraries and social welfare programs. This accommodative approach attracts many irregular immigrants from Punjab and other neighbouring countries, where regularisation is very difficult, if not impossible. Inderjit, 48 , male, irregular immigrant, explains "once you enter Spain irregularly, nobody detains or deports you. Therefore, people feel that it is just a matter of entrance by any means, and later on, they will get regularized one day."

The number of irregular immigrants also depends upon the residency permit renewal laws. Particularly, in Italy most of the Punjabi immigrants enter with a regular visa, but due to the failure of its renewal, they become irregular. As explained by Manjit, 36 , male, irregular immigrant, "I entered Italy with a legal working visa of 9 months, I paid 8 lakh rupees for that visa, but when I arrived here, I had no work. So when the visa expired, I became irregular". Similarly, there are many Punjabi immigrants in Spain who have lost their initial temporary residency permits because of the lack of jobs or by spending more than six months continuously or total 10 months out of Spain in the first five years of their legal stay. Ravinder, 34, male, irregular migrant, "I got papers in 2012, but due to the shortage of work I failed to pay the required amount of tax. Consequently, I lost the residency permit and became irregular again". In Italy, the number of irregular immigrants created by the state's immigration laws was much higher as compared to Spain. 


\section{Consequences of Punjab irregular immigration}

Major consequences of Punjabi irregular immigration for different actors involved in it (Fig. 2), are discussed below:

\section{Consequences for the family members of irregular migrants}

The families of irregular migrants incur a huge economic and psychological costs of irregular migration, which are not fully identified and analysed yet. The price paid to the human smugglers is often paid by mortgaging the ancestral land or property. It indebts whole family for several years, until the whole debt repaid through remittances. Sometimes, when things go wrong, it also leads to the loss of mortgaged land and property. As explained by Kartar, 56, male, father, "I paid 9 lakh rupees to an agent for my son's journey by mortgaging my ancestral land. He [son] spent three months in the journey, and another six months without work in Italy. Now the debt money has increased to 1.2 million rupees. I think I have to sell my land to repay the debt". The loss is not only economic, some respondents also highlight the loss of human capital due to irregular migration, which sometimes results in the shutdown of family businesses. As stated by Nirmal, 59, male, father, "I had a dairy business. I was expecting that my son will run my business, but he decided to emigrate irregularly. Hence, I shut-down the business".

For migrant families, irregular migration also causes a lot of psychological stress. Owing to the dangers involved, the first few days of the journey are very stressful, as the future of the whole family depends upon the success of the migrant's journey. This fear and psychological stress is rightly highlighted by Balbir, 48, female, mother, "my elder son was only 17 when he started his journey. When he moved from Moscow, we lost all contact with him. For the next three months, we didn't receive any information. It was the toughest period of my life". As irregular migrants cannot return to their countries or reunite their families, irregular migration also contributes to the creation of many divided families in Punjab. In these families, mostly men migrate first, and women take care of kids and property. Often kids in these families spend most of their childhood with a single mother, which affects their psychological growth. Rajbir, 34, female, wife, explains, "My children were very young when their father decided to emigrate [irregularly] to Europe. He sent remittances, but due to his irregular status he can't come to India or sponsor us to Italy. My kids are growing without their father." It has become a hard reality of many families in Punjab, divided by the borders and immigration laws. It also multiplies the responsibilities of single mothers, who often find themselves stressed and helpless.

Figure 2. The consequences of Punjabi irregular immigration for immigrants, their family members and the host country. 


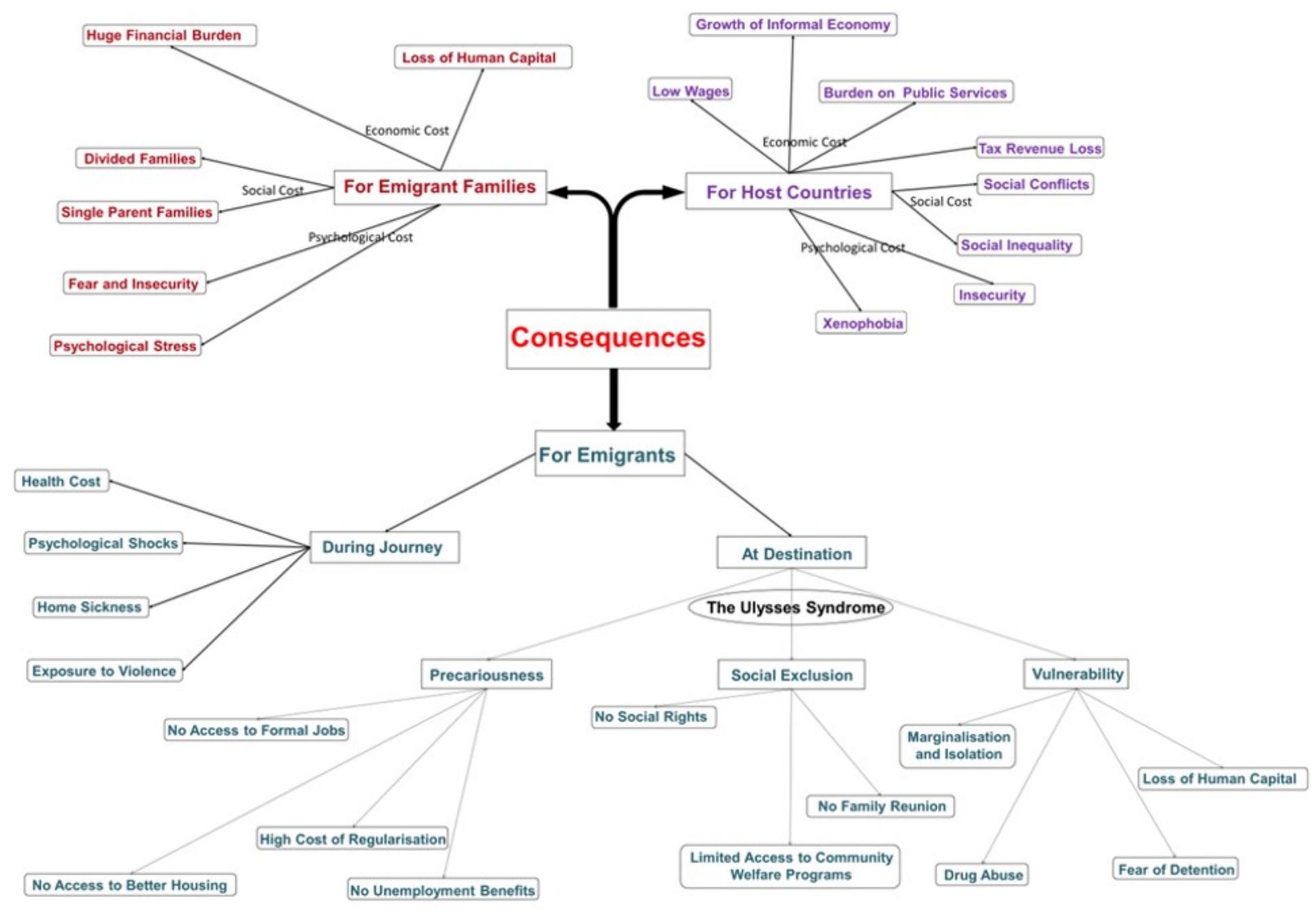

Source: Own elaboration.

\section{Consequences for irregular migrants}

The irregular migrants suffer huge financial, physical and psychological stresses during the journey and at the countries of destination, which are discussed below:

During the Journey:

The journey of irregular emigrants, especially who opt for the donkey flights (Smith, 2014), is full of hardships. Often they pass through very inhumane living conditions and possibly fatal situations to reach their destinations. As explained by Inder, 23, male, irregular migrant, "conditions were worst in the Sahara Desert. The agents [human traffickers] used to bring food and water once a day, and we had to survive till the next day. To cross the international borders, we used to walk at night. We were exposed to mosquitos and other parasites, which were the cause of fever and deaths. Agents warned us that if we fell sick they would leave us in the desert and move ahead". Some respondents also highlight the suffering from home-sickness, during their long stays in refugee camps or sometimes in jails. Sonu, 25, male, irregular migrant, explains, "First few days of the journey were good. We were excited, but when we entered a refugee 
camp and the days converted to weeks and weeks to months, I started to get homesick. I knew that I cannot return home empty handed". Harsh conditions during the journey, exposure to violence and death of group members left irregular migrants with psychological traumas that haunt them for the rest of their lives. Kamal, 34, male, irregular immigrant, says, "I have very disturbing memories of my journey. One of my friends died on the way to Europe. I gave the news of his death to his family...even today [after 10 years] sometimes I feel very sad for him".

\section{At the destination:}

The sufferings of irregular immigrants do not finish even when they arrive at their desired destinations. In fact, most often they find themselves in a situation of extreme precariousness, social exclusion and high vulnerability. Their dreams of better life shattered when they face the hard reality of irregular immigrants in Europe. They suffer a psychological shock, also termed as Ulysses Syndrome (Diaz-Cuellar et al. 2013). As explained by Avtar, 28, male, irregular migrants, "conditions in Italy were a brutal shock for me... my dreams of good life were shattered in the fields of Latina, where I used to live a life of misery, many times worse than India... I got depressed and started consuming alcohol and drugs". As most of the irregular immigrants pay large sums of money for their journey, they suffer huge mental stress to repay the debt. This stress increases with poor working and living conditions, and results in acute depression among irregular immigrants. As explained by Jasjit, 32, irregular migrant, "I paid 9 lakh rupees to agents. The money was borrowed from a money lander by mortgaging my house and land. I am depressed because the debt is growing fast, and I don't have a job".

The major problem for irregular migrants in Europe is the lack of work permits that limits their access to formal jobs. In Italy and Spain, employers are legally bound to sign a work contract with workers. All workers are obliged to present their legal work and stay permit in the country to sign these work contracts. As explained by Sandeep, 34, male, irregular migrant, "Here [in Spain] without legal work and residence permit, one can't sign a work contract with any firm." Therefore, the only way left for irregular migrants is to work in the shadow economy, which leads to their harsh exploitation by local employers and sometimes by their own countrymen. As explained by Amrit, 32, male, irregular migrant, "Initially, I got some work in a cow shed. There nobody asked me for papers [legal work permission], but the employer used to pay me only 25 euros per day and treat me like a slave". Moreover, irregular immigrants do not receive any unemployment benefit, if they lose their job for any reason. The irregular status among immigrants also leads to the loss of human capital earned in the home country. Many respondents have pointed out that the traits learned in India have become useless due to the lack of legal work permit in the host countries. Ranjit, 28, male, irregular worker, explains, "I have done a Master's degree in India, but owing to my irregular status here [in Spain] I am not allowed to work as a teacher. Consequently, all my studies go in vain". Sometimes, the irregular status also exposed migrants to criminal activities and drug abuse. Jaggi, 35, male, irregular migrant, says, "I didn't get any job due to the lack of papers [legal permit of work] and skills. So I start selling beers and water bottles on the streets of Barcelona. During this time, I come in contact with drug peddlers. They offered me work and I accepted their offer. Initially, I earned a lot of money by selling drugs, but slowly I started consuming these drugs". 
Irregular immigrants also suffer from poor living conditions and no access to better housing. They cannot rent an apartment. It forces them to share houses with other migrants. It reduces their quality of life and sometimes exposes them to health problems. Param, 31, male, irregular immigrant, explains "I can't rent an apartment in Italy. My friends allowed me to stay in their apartment by paying some monthly rent... Good apartments are costly, so we live in substandard conditions, which is affecting my health". The process of regularisation also puts huge financial burden on irregular immigrants. The expanses of regularization include the money paid for a work contract, legal taxes and the lawyers' fees. Harwinder, 34, male, irregular migrant, explains, "In Spain, a full-time work contract is a necessary prerequisite for regularisation. Here local businessmen charge 8 to 10 thousand euros for a work contract".

In addition to the economic hardship, irregular immigrants also suffer from social exclusion, as their irregular status restrict them to participate in social gatherings and public meetings. In Spain, irregular immigrants are allowed to register in municipal registers and use some basic public services, like health and education services, but most of them hesitate to use these services because of the fear of detention and deportation. In Italy, they have no right to get registered in municipal registers or apply for educational institutes. Even the health services are only provided during emergencies. This makes them more vulnerable, with no social security and protection from law. As explained by Gurjit, 28, male, irregular immigrant, "In Italy irregular migrants cannot use community services. Mostly they live in isolation, far from host society and city centres, ...hiding from the police". Additionally, irregular immigrants cannot reunite their family members. The separation from families and isolation affect their mental health. Sukhbir, 34, male, irregular immigrant, says, "I cannot go to India or reunite my family in Spain. For the last 7 years, I am far from my family. It makes me very sad".

\section{Consequences of irregular migration for host countries}

Irregular immigration has several negative effects on the economic and social setup of Italy and Spain. Firstly, in the economic sphere, it is considered to be the prime motor behind the functioning of the informal economy. As explained by Paloma, 36, female, social worker, "Mostly irregular migrants work in small businesses, some of them provide domestic services, but all without formal contracts." Some of the respondents also blame irregular immigrants for increasing competition in the labour market and stagnation of wages, as most of the irregular immigrants accept harsh working conditions and low wages. It also affects the upward socioeconomic mobility of other regular migrants. Rajbir, 38, male, regular migrant, says, "If irregular migrants occupy all jobs, it will leave many regular migrants, like me, or native workers without work. As they accept low wages, it affects our salaries also". As most of the irregular workers work in the shadow economy, it also reduces the tax revenue of the local governments. Employers deny all labour rights to irregular workers and avoid taxes without any repercussions. Kewal, 45, male, agriculture worker, explains, "Farmers in Latina like to hire irregular workers, because they work hard and demand lower wages. The farmers don't pay tax and enjoy the freedom to sack any worker whenever they want". Some respondents blame irregular migrants for the increased burden on the public services. In Spain free health and education services are provided to all residents 
irrespective of their legal status. Some natives criticise the use of public services by irregular immigrants, as they do not contribute to the system. Jesus, 45, male, hospital worker, says "Government hospitals can't deny treatment facilities to any sick person. As irregular immigrants don't pay any tax, the expenses fall on the shoulders of other taxpayers."

Irregular immigration increases the social inequality by creating a class of people who provide essential services in agriculture, hospitality and domestic care sectors and live in subhuman conditions without any role and representation in social and political spheres of the host societies. Mar, 36, female, social worker, explains, "Irregular immigration has created a class of people, who are deprived of all socioeconomic and political rights and live on the periphery of the host society". Some of the respondents relate it with the increased level of insecurity in several neighbourhoods with a high concentrations of immigrant population. Paco, 48, male, farmer, says, "When I was young, we used to keep our doors open and kids used to play outdoors. But now with this uncontrolled immigration, it is very dangerous to leave doors open and allow kids to play alone outside". As irregular immigrants do not have legal permission to work and stay, sometimes they become an easy target for organised crime groups who use them in illegal activities. The participation of a tiny fraction of irregular immigrants in illegal activities increases xenophobia and intolerance among native population towards all immigrants. As explained by Albert, 52, male, teacher, "all streets and square parks are now full of immigrants -predominantly young coloured males of different origins-, sometimes it scares me. Actually, everybody is coming from different cultural backgrounds, you can't predict what they think about you and your social norms". Social media also plays a significant role in spreading rumours about irregular immigrants. The incorrect depiction of all irregular immigrants as criminals have resulted in the rise of right wing and populist parties in many European countries.

\section{Conclusions}

With a detailed analysis of the interviews conducted in Spain, Italy and India, this paper explores the major causes and consequences of Punjabi irregular migration to Italy and Spain. The main causes behind the irregular emigration from Punjab includes low human capital, less accessibility to legal channels, emergence of irregular immigration business, corruption, lack of political will in Punjab. Similarly, the main causes behind the irregular Punjabi immigration to Italy and Spain includes the availability of informal jobs in the shadow economy, support from the social networks, possibility to get regularised and the accommodative model of immigrant integration in both countries. As per the consequences of irregular immigration, the only beneficiaries are the intermediaries (travel agents or human smugglers), who charge huge sums of money by trafficking people to European countries, and the employers, who exploit irregular workers to maximise their profits. The migrants, their family members in Punjab and the host society suffer huge economic, social and psychological costs of irregular immigration.

In Spain and Italy, irregular immigrants have become a structural part of their economies and societies (as explained by Cvajner and Sciortino, 2010). In both countries, 
there is a huge demand for cheap manual labour in agriculture, hospitality and domestic services and Punjabi irregular immigrants are willing to do these jobs at a very low wages. This interdependence encourages continuous irregular immigration. Punjabi irregular migration can be explained as a form of permissive irregular migration (Hillman and Weiss, 1999), which is visible in the shadow economies of both countries, but ignored by the authorities to help local agriculture (Cheese industry in Parma region, leather industry in Vicenza and agriculture in Latina in Italy, Murcia in Spain) and businesses (restaurant and hospitality services in Rome and Barcelona). As irregular immigration has become a permanent feature of both sending and receiving countries, efforts should be made on both ends of this migration process to reduce the vulnerability of migrants and their families and help the host economies to flourish with regular supply of workers.

To control the human trafficking and irregular emigration from Punjab, firstly, the Indian government has to invest in the human capital, so that the young workers who want to emigrate from the country, can find a job in their homeland or migrate legally to give their services in particular sectors that requires foreign workers with some specific skills. Secondly, youth awareness programs, should be started to provide correct information about the travelling and working conditions in Europe to the rural youth in Punjab, so that they do not become easy prey for the fraudulent travel agents and human traffickers. Thirdly, strict laws should be made to control the network of human smuggling and corruption in the immigration department in India. And finally, some legal channels should be opened for the unskilled workers form Punjab by signing bilateral agreements with the EU countries that need manual labour. Similarly, in the host countries, firstly, the strict punishments should be given to the people engaged in human smuggling. Secondly, some economic sanctions should be imposed on the employers who hire irregular immigrants and they should be obliged to pay the cost of regularisation of their irregular workers. Thirdly, legal channels should be established to provide labour to the local farmers and industrialists to fulfil their needs in a more transparent and efficient way, and finally, the process of residency permit renewal should be made easier for the workers who enter legally in the country.

\section{Acknowledgements:}

This research is funded by the $\mathrm{I}+\mathrm{D}+\mathrm{I}$ project Demography, Migrations and New Statistics Frontiers: Big Data, Continuous Population Registers and Administrative Records(CSO2017-85670-R) funded by the Spanish Ministry of Economy, Industry and Competitiveness (PI: Andreu Domingo).

\section{REFERENCES}

Alañón A and Gómez-Antonio M (2005) Estimating the size of the shadow economy in Spain: a structural model with latent variables. Applied Economics 37(9): 1011-1025. 
Aiyar SSA (2013) Why Punjab Has Suffered Long, Steady Decline. In: Debroy B, Bhandari L, Gulati A, and Aiyar SSA (eds) Economic Freedom of the States of India 2012. New Delhi: Academic Foundation, pp. 33-65.

Andersson R (2016) Europe's failed 'fight' against irregular migration: ethnographic notes on a counterproductive industry. Journal of Ethnic and Migration Studies 42(7): 1055-1075.

Baldwin-Edwards M (2009) Towards a Theory of Illegal Migration: historical and structural components. Third World Quarterly 29(7): 1449-1459.

Barrier NG and Dusenbery VA (1989) The Sikh Diaspora: Migration and the Experience Beyond Punjab. Delhi: Chanakya Publication.

Bhawra VK (2013) Irregular Migration from India to the EU: Evidence from the Punjab. CARIM-India Research Report 2013/03, Robert Schuman Centre for Advanced Studies, San Domenico di Fiesole (FI): European University Institute.

Bommes M (2003) The Shrinking Inclusive Capacity of the National Welfare State: International Migration and the Deregulation of Identity Formation. Comparative Social Research 22(1): 43-67.

Calavita K (1998) Immigration, Law, and Marginalization in a Global Economy: Notes from Spain. Law and Society Review 32(3): 529-566.

Castles S, Cubas MA, Kim C, and Ozkul D (2012) Irregular Migration: Causes, Patterns, and Strategies. In: Omelaniuk I (eds) Global Perspectives on Migration and Development. Global Migration Issues, vol 1. Dordrecht: Springer.

Clandestino (2009) Comparative policy brief - Size of irregular population. Hamburg: Clandestino Research Project (accessed 10 July 2017). 
Cvajner M and Sciortino G (2010) Theorizing Irregular Migration: The Control of Spatial Mobility in Differentiated Societies. European Journal of Social Theory 13(3): 389404.

De Genova NP (2002) Migrant Illegality and Deportability in Everyday Life. Annual Review of Anthropology 31(1): 419-447.

Diaz-Cuellar AL, Ringe HA and Schoeller-Diaz DA (2013) The Ulysses Syndrome: Migrants with Chronic and Multiple Stress Symptoms and the Role of Indigenous Linguistically and Culturally Competent Community Health Workers. [online] 2013. (http://www.panelserver.net/laredatenea/documentos/alba.pdf, accessed 24 Aug. 2018).

De Haas H (2011) The Determinants of International Migration: Conceptualizing Policy, Origin and Destination Effects. DEMIG Project Paper No. 2. IMI, University of Oxford.

Düvell F (2006) Irregular Migration: A Global, Historical and Economic Perspective. In: Düvell F (eds) Illegal Immigration in Europe: Beyond Control? Basingstoke: Palgrave Macmillan, pp. 14-39.

Düvell F (2008) Clandestine Migration in Europe. Social Science Information, 47(4): 479-497.

Düvell F (2011a) Paths into Irregularity: The Legal and Social Construction of Irregular Migration. European Journal for Migration and Law 13(3): 275-295.

Düvell F (2011b) Irregular migration. In: Betts A (eds) Global Migration Governance Oxford: Oxford University Press, pp. 78-108.

Düvell F and Jordan B (2003) Immigration Control and Economic Migration Management in the UK: Organisational Culture, Implementation, Enforcement and Identity Process in Public Services. Journal of Ethnic and Migration Studies, 29(2): 299-336. 
European Migration Network (2013) Practical measures to reduce irregular migration. Luxembourg: Publications Office. http://irregular migration.net/fileadmin/irregularmigration/dateien/4.Background_Information/4.5.Update_Reports/Vogel_2015_Upd ate_report_Germany_2014_fin-.pdf (accessed on 12th March 2018).

Finotelli C and Arango J (2011) Regularisation of unauthorised immigrants in Italy and Spain: determinants and effects. Documents d'Anàlisi Geogràfica 57(3): 495-515.

Frontex report (2017) Risk analysis report 2018. http://statewatch.org/news/2018/mar/eufrontex-report-risk-analysis-2018.pdf. (accessed on 24th Aug. 2018)

Gallo, E. 2012. 'Creating gurdwaras, narrating histories. Perspectives on Sikh diaspora in Italy'. South Asian Multidisciplinary Academic Journal (SAMAJ), 6 [Online Publication Available at: http://samaj.revues.org/3431\#text].

Garcés-Mascareñas B (2010) Legal production of illegality in a comparative perspective: The cases of Malaysia and Spain. Asia Europe Journal 8(1): 77-89.

Garha NS and Domingo A (2017) Sikh Diaspora and Spain: migration, space and hypermobility. Diaspora Studies 10(2): 193-216.

Garha NS and Paparusso A (2018) Fragmented integration and transnational networks: a case study of Indian immigration to Italy and Spain. Genus 74(1): 1-12.

Garha NS and Domingo A (2019) Migration, Religion and Identity: A Generational Perspective on Sikh Immigration to Spain. South Asian Diaspora 11(1): 33-50.

Garha NS (2019): Indian immigration to Italy: concentration, internal mobility and economic crisis, South Asian Diaspora, DOI: 10.1080/19438192.2019.1609295

Garha NS (2020) Masculinity in the Sikh Community in Italy and Spain: Expectations and Challenges. Religions 11, 76; doi:10.3390/rel11020076. 
Geddes A and Taylor A (2013) How EU Capacity Bargains Strengthen States: Migration and Border Security in South-East Europe. West European Politics 36(1): 51-70.

González-Enríquez C (2009) Spain, the Cheap Model. Irregularity and Regularisation as Immigration Management Policies. European Journal of Migration and Law 11(1): 139-157.

Hanson GH (2007) The Economic Logic of Illegal Immigration. CSR 26, Council on Foreign Relations, New York.

Hillman AL and Weiss A (1999) A theory of permissible illegal immigration. European Journal of Political Economy 15(4) 585-604.

Iglitzka C, Gmay K and Maroukis T (2011) Irregular Migration and Informal Economy in Southern and Central-Eastern Europe: Breaking the Vicious Cycle? International Migration, 49(5): 129-156.

Jahn A and Straubhaar T (1998) A Survey of the Economics of Illegal Migration. South European Society and Politics 3(3): 16-42.

Jordan B and Duvell F (2002) Irregular Migration: The Dilemmas of Transnational Mobility. Cheltenham: Edward Elgar.

King R and Zontini E (2000) The role of gender in the South European immigration model. School of European Studies Papers 60: 35-52. University of Sussex.

Kovacheva V and Vogel D (2009) The size of the irregular foreign resident population in the European Union in 2002, 2005 and 2008: aggregated estimates. Working paper No.4, Hamburg Institute of International Economics (HWWI), Database on Irregular Migration.

Krause M (2011) Stateless people and undocumented migrants: An Arendtian perspective. In: Caroline Sawyer and Brad K. Blitz (eds) Statelessness in the 
European Union. Displaced, Undocumented, Unwanted. Cambridge: Cambridge University Press, pp. 22-40.

Kumar S (2009) Human Trafficking in Punjab. Journal of Punjab Studies 16(1): 89-111.

Lee ES (1966) A Theory of Migration. Demography (3)1: 47-57.

Massey DS and Capoferro C (2004) Measuring Undocumented Migration. International Migration Review 38(3): 1075-1102.

Morehouse C and Blomfield M (2011) Irregular Migration in Europe. Migration Policy Institute, Washington, D.C.

Reyneri E (2003) Immigration and the underground economy in new receiving South European countries: manifold negative effects, manifold deep-rooted causes. International Review of Sociology 13(1): 117-143.

Sabater A and Domingo A (2012) A New Immigration Regularization Policy: The Settlement Program in Spain. International Migration Review 46(1): 191-220.

Saha JK (2009) Smuggling of Migrants from India to Europe and in Particular to the UK: A Case Study on Punjab and Haryana. Delhi: United Nations Office on Drugs and Crime (UNDOC).

Sahai, Paramjit, and Kathryn Dominique Lum. 2013. Migration from Punjab to Italy in the Dairy Sector: The Quiet Indian Revolution. CARIM India RR2013/10. Fiesole: Robert Schuman Centre for Advanced Studies, San Domenico di Fiesole (FI), European University Institute.

Samers M (2004) An Emerging Geopolitics of 'Illegal' Immigration in the European Union. European Journal of Migration and Law 6(1): 27-45.

Schneider F and Enste D (2000) Shadow Economies: Size, Causes, and Consequences. Journal of Economic Literature XXXVIII: 77-114. 
Smith N (2014) Donkey Flights: Illegal Immigration from the Punjab to the United Kingdom. Migration Policy Institute Report, online February 2014, http://www.migrationpolicy.org/research/donkey-flights-illegal-immigration-punjab-united-kingdom.

Spena A (2016) Resisting Immigration Detention. European Journal of Migration and Law 18(2): 201-221.

Strauss A and Corbin J (1994) Grounded theory methodology. In: Norman YSL and Denzin K (eds) Handbook of qualitative research vol. 17. Los Angeles: Sage Publications, pp. 273-285.

Tatla DS (1999) The Sikh Diaspora: The Search for Statehood. London: UCL Press.

Uehling GL (2004) Unwanted migration: combating and unwittingly creating irregular migration in Ukraine. New Issues in Refugee Research 109: 1-18.

United Nations Office on Drugs and Crime (2009) Smuggling of Migrants from India to Europe and in particular to UK: A study on Punjab and Haryana. New Delhi: UNODC.

Zaidi A (2007) Craze to go West. Frontline 24(11): 2-15. 